\title{
Step by step: a participatory action-research framework to improve social participation in coastal systems
}

\author{
Natalia de Miranda Grilli \\ Mariana Martins de Andrade \\ Luciana Yokoyama Xavier \\ Cláudia Regina Santos \\ Fernanda Terra Stori \\ Cauê Dias Carrilho \\ Felipe Otavio Nunes
}

\author{
Caiuá Mani Peres \\ Melissa Vivacqua \\ Thiago Zagonel Serafini \\ Paulo Antonio de Almeida Sinisgalli \\ Cristiana Simão Seixas \\ Pedro Roberto Jacobi \\ Alexander Turra
}

I Oceanographic Institute of São Paulo University, São Paulo, SP, Brazil.

II Oceanographic Institute of São Paulo University, São Paulo, SP, Brazil.

D III Oceanographic Institute of São Paulo University, São Paulo, SP, Brazil.

(D) IV Oceanographic Institute of São Paulo University, São Paulo, SP, Brazil.

$\checkmark$ Oceanographic Institute of São Paulo University, São Paulo, SP, Brazil.

${ }^{V I}$ Institute of Energy and Environment of São Paulo University, São Paulo, SP, Brazil.

VII School of Arts, Sciences and Humanities of São Paulo University, São Paulo, SP, Brazil.

D VIII Oceanographic Institute of São Paulo University, São Paulo, SP, Brazil.

D IX Institute of the Sea of São Paulo Federal University, Santos, SP, Brazil.

D $x$ Center for Marine Studies of Paraná Federal University, Pontal do Paraná, PR, Brazil.
Abstract: Social participation enriches decision-making and is considered a civil right in many democratic countries, despite remaining a challenge. This paper presents evidence and discusses the evolution of social participation in the Araçá Bay (Southeastern Brazil), as a result of participatory action-research. Over three years, a process of social mobilization and participatory environmental assessment and planning engaged local stakeholders and resulted in a sustainable development plan. Enhanced social participation was evidenced by: (1) building trust among participants; (2) increasing knowledge of social-ecological features of Araçá Bay; (3) acknowledging different perspectives and interests about the bay; and (4) improving the understanding of management dynamics and institutions. The process led to the emergence of a local stewarded group that has the potential to foster the implementation of the sustainable development plan.

Keywords: Social learning; Social-ecological systems; Araçá Bay.

São Paulo. Vol. 24, 2021

Original Article

DOI: http://dx.doi.org/10.1590/1809-4422asoc20190255r1vu2021L1AO 
${ }^{x I}$ School of Arts, Sciences and Humanities of São Paulo University, São Paulo, SP, Brazil.

xII Center of Environmental Research and Studies of Campinas State University, Campinas, SP, Brazil.

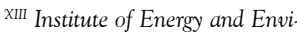
ronment of São Paulo University, São Paulo, SP, Brazil.

XIV Oceanographic Institute of São Paulo University, São Paulo, SP, Brazil.

\section{Introduction}

Social participation in ecosystem assessment and decisionmaking processes is a democratic right and can promote resilient, better informed and context-adapted solutions to environmental management (BERKES, 2009; REED, 2008), as well as build trust, reduce conflicts, and facilitate learning (DE VENTE et al. 2016; DERAK et al., 2018). Social participation ranges from centralized societies, in which decision-makers are unwilling to share power and no genuine social participation exists (i.e. lower degrees); involved communities, in which social stakeholders act as consultants with no actual influence on decisions (i.e. intermediate degrees); and empowered citizens, in which decision-makers and community members collaborate, or the community retains full managerial power (i.e. higher degrees) (ARNSTEIN, 1969).

Here we understand social participation as public engagement that allows those affected by a decision to actively influence that decision. Thus, participation surpasses the presence of stakeholders in decision-making arenas and embed their interests in the decision (EMPINOTTI, 2011). This process should include all stakeholders - governmental and non-governmental agencies; community and sectoral organizations; scientists; and business companies (BROWN et al. 2002, REED et al. 2018).

Meaningful participation must overcome obstacles related to representativeness, access to resources (e.g. information, budget and time), clear objectives, transparency, knowledge and power balance, language barriers, and enforcement (PETERSON, 2011; TRIMBLE; ARAÚJO; SEIXAS, 2014). Furthermore, it is important to build capacities on individuals that are excluded from political, economic, social, environmental, and cultural processes (ARNSTEIN, 1969).

In Brazil, social participation is a pillar of society's redemocratization, entrenched in the Federal Constitution of 1988. The creation of participatory forums was based on the belief that they would foster democratization and increase management effectiveness (FARIA; RIBEIRO, 2011). Such forums are an instrument of many sectoral policies (as environmental, water management, health, and education) to foster horizontal practices, empower vulnerable and excluded social actors, and strengthen associative bonds. However, despite existing legislation, socio-economic inequality is still reflected in political and decision-making processes (ALMEIDA; CUNHA, 2011). In that sense, social participation should be encouraged and enriched 
in different ways beyond regulation enforcement, such as through participatory actionresearch (PAR) (McTAGGART, 1997).

PAR has become a tool for community involvement in environmental management (SEIXAS, 2005) by seeking to create alternative methods of natural resource sustainability and strengthen social participation (CHAMBERS, 1994; CHEVALIER; BUCKLES, 2009). PAR may increase social capital and improve relations between researchers and local communities, which helps to develop appropriate management strategies through a collaborative and adaptive way of thinking and working (ARNOLD; FERNANDEZGIMENEZ, 2007). As the extent and quality of social participation increase, societal capacities for collaborative inquiry and innovative action are strengthened and foster adaptive and transformative capacities of environmental governance and management systems (BERKES, 2009). Therefore, PAR may enrich resilience in ecosystems and communities (BALLARD; BELSKY, 2010).

Resilience is especially relevant when considering complex social-ecological systems, a concept that emphasizes the perspective of the human presence in nature and assumes that the border between the social and ecological realms is artificial and arbitrary (BERKES; FOLKE, 1998; MOBERG; SIMONSEN, 2014). Since social-ecological systems often face threats and crises, their resilience depends on science-based planning, management, and conservation strategies, which may consider traditional ecological knowledge; strengthen social networks and adaptive co-management; support stakeholders' awareness and vigilance for the sustainability of ecosystem services; and, nurture social learning (STORI et al., 2019a).

Social learning is a process through which stakeholders interact and collaboratively construct new meanings and strategies to work together and solve complex environmental problems (BERKES, 2009; GARMENDIA; STAGL, 2010; MURO; JEFFREY, 2008; REED et al., 2010). Successive social learning loops occur when the triumph of overcoming a problem enhances collective abilities of the group to deal with more complex issues and strengthens internal and external institutional arrangements (BERKES, 2009). In social learning processes, participants are engaged in building knowledge, recognizing system complexity, transforming social context, and changing the appraisal of facts (GARMENDIA; STAGL, 2010).

In this paper, we describe and critically analyze the achievements of a PAR process that aimed at improving social participation in coastal management.. The PAR was guided by social learning principles and by a broad understanding of the social-environmental complexities of the Southeastern coast of Brazil, where the study site is located. Araçá Bay was chosen due to socioeconomic pressures that have been negatively impacting its sustainability and the livelihood of the local community, which has been historically excluded from management processes (see details below).

We first present Araçá Bay's social-ecological context followed by the PAR framework and strategies. We then present evidence and discuss the improvements in social participation enabled by the PAR and highlight the remaining challenges to local longterm participatory management. 


\section{Context of the study area}

Araçá Bay lies in the municipality of São Sebastião, on the Northern Coast of São Paulo State, Brazil (Figure 1). Araçá Bay is a singular place but representative of the Brazilian coastline. It is subjected to multiple uses and conflicts over current and future uses; political disputes of interests and power; inefficient environmental management, including the non-implementation of institutionalized environmental protected areas. The community that benefits from the bay is also representative of the fragile situation of many Brazilian traditional coastal communities as they are alienated and excluded from decision-making processes and have low social capital (SANTOS; TURRA, 2017; NUNES, 2016).

Figure 1: The Araçá Bay (a) and its location in relation to the Northern Coast of São Paulo State (b) and Brazil (c).

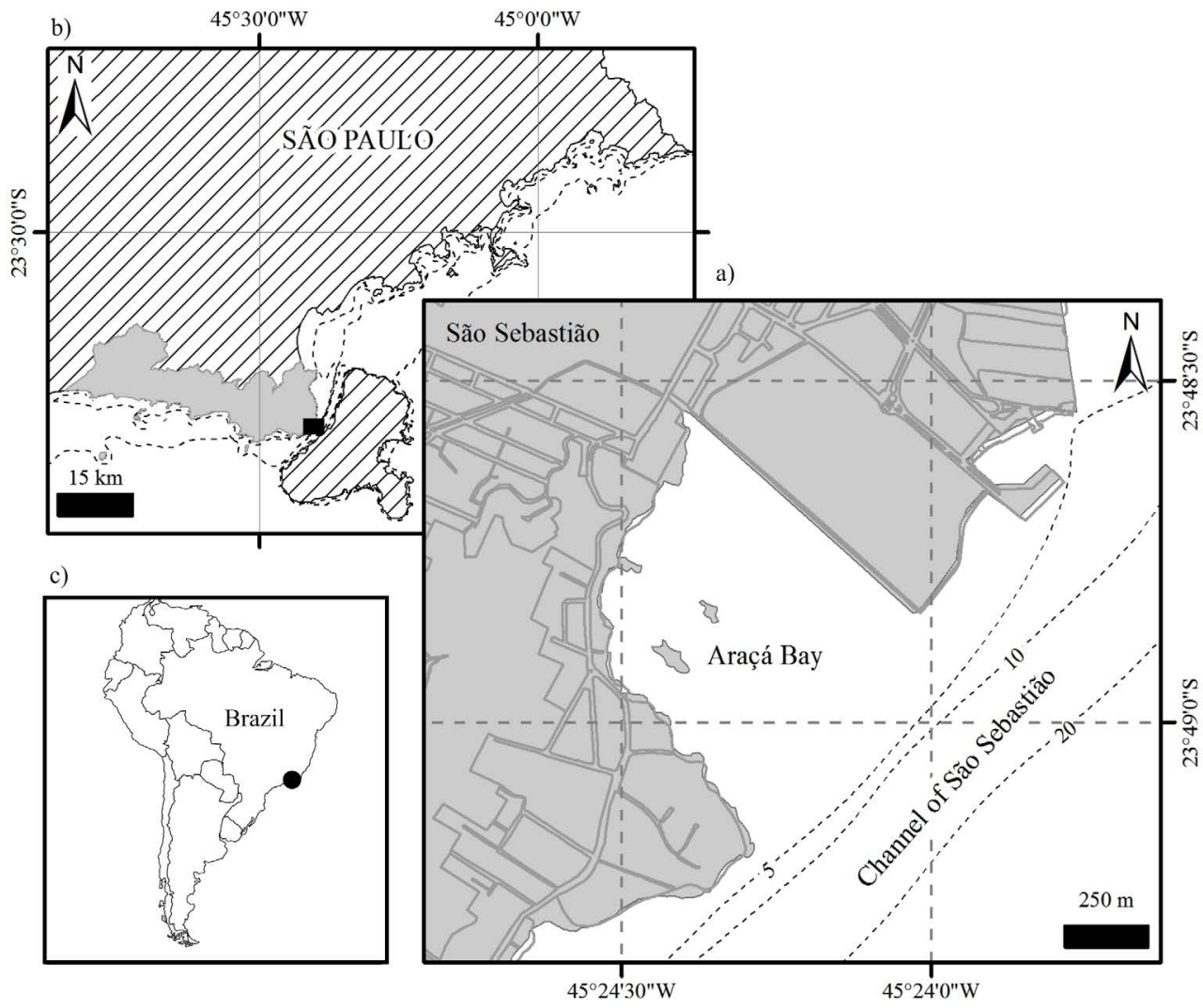

Source: authors (2021). 
The bay has faced several transformations and pressures due to infrastructure projects, such as the installation the São Sebastião Port since the 1930s and the construction of an undersea sewage duct of a sanitation company during the 1970s and 1980s (PERES et al., 2016). The impacts of these projects and other surrounding pressures, such as irregular human occupation, oil spills, lack of proper sewage treatment, and marine litter, had led to a worrying social-environmental degradation of the bay (PERES et al., 2016; TURRA et al., 2017).

Despite these impacts, Araçá Bay has been remarkably resilient and is one of the most biodiverse areas along the Brazilian coast (AMARAL et al., 2010, 2016). The bay is composed of 550,000 $\mathrm{m}^{2}$ of diverse coastal habitats such as sandy beaches, rocky shores, mangrove patches, and intertidal flats, which sustain 13 ecosystem services recognized by local actors, including food supply, harboring vessels, access to the sea, effluent depuration, hosting scientific activities and carbon stocking (CARRILHO; SINISGALLI, 2018). The environmental relevance of the bay is expressed by its inclusion in two protected areas, the non-implemented Municipal Protected Area of Alcatrazes and the Marine Protected Area of the Northern Coast of São Paulo State (APAMLN) that has yet to establish the area of the Araçá Bay under its management. A range of stakeholders benefits from directly or indirectly using the bay or affects its governance (Figure 2), which can generate local conflicts (PLDS/Araçá, 2016). 
Figure 2. Araçá Bay's main stakeholders, uses, and roles

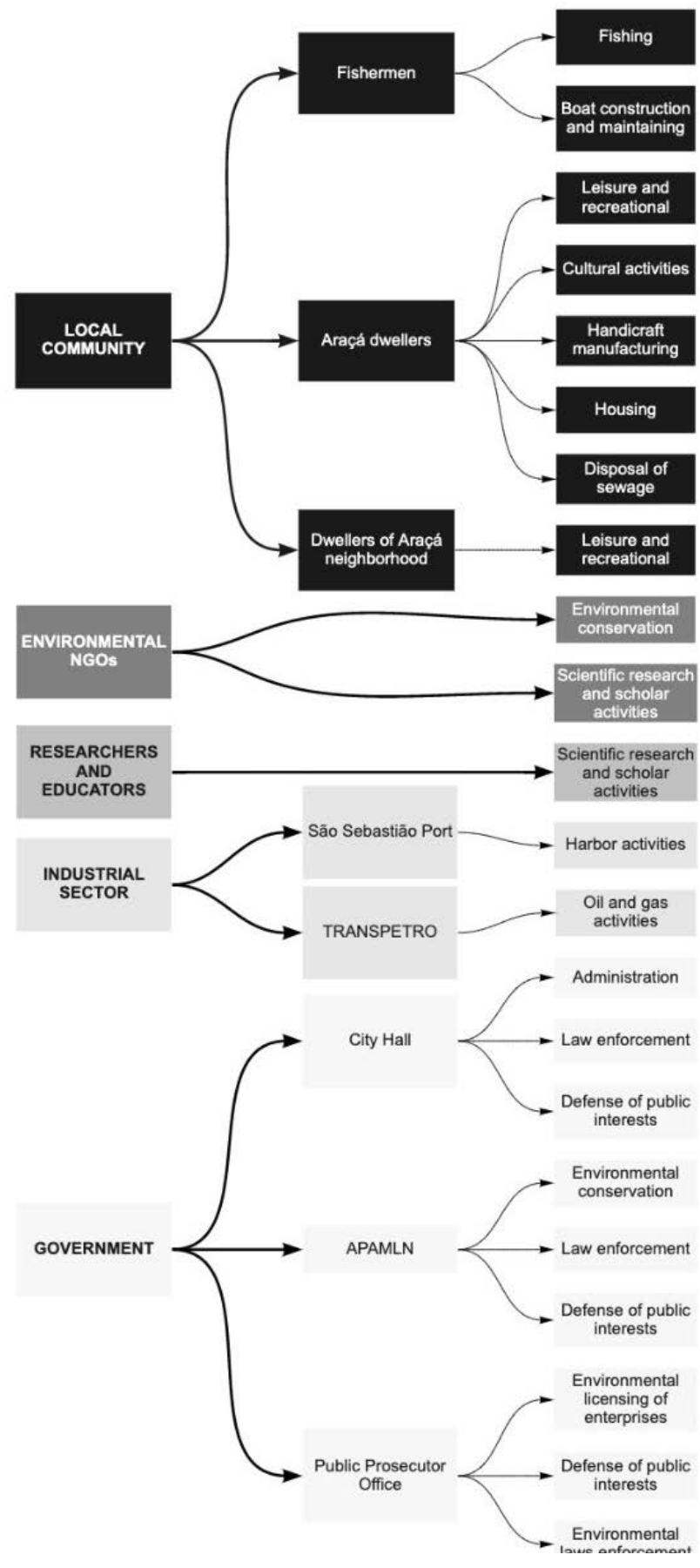

Source: authors based on PLDS/Araçá (2016). TRANSPETRO = Oil Terminal ; NGOs = Non-governmental organizations; APAMLN = Marine Protected. Area of the Northern Coast of São Paulo State. 
Since 2010, Araçá Bay has been facing another threat: the São Sebastião Port expansion proposal, which would suppress at least one-third of the bay and compromise the provision of ecosystem services (TURRA et al., 2017). During this period, regional stakeholders from the Northern Coast of São Paulo state, such as environmental nongovernmental organizations (NGOs), organized several events against port expansion, but with low involvement from Araçá Bay dwellers (SANTOS; BORGES; TURRA, 2017). The Public Prosecutor's Office legally contested the project, leading to the cancelation of the environmental license granted by the Brazilian Institute of Environment and Renewable Natural Resources (IBAMA) ${ }^{1}$ (NETO et al., 2017). The participatory process analyzed here was motivated by the risks of harbor expansion over the Araçá Bay and occurred in parallel to this legal dispute.

In addition to the existing use conflicts, he local social capital was low, i.e. members of the local community members did not trust one another and they did not participate in any local management forums to discuss Araçá Bay issues (SANTOS, 2012; NUNES, 2016). Thus, there was a need to create a neutral arena in which discussions about conflicting uses and future scenarios for Araçá Bay could be carried out.

In terms of scientific research, Araçá Bay has been studied for at least 60 years and scientists describe it as an open-air laboratory and classroom (AMARAL et al., 2016). Most of this research was based on Natural Sciences (AMARAL et al., 2010), and there was a need to understand the multiple dimensions of the bay (i.e., environmental, economic and social) in order to support management strategies (AMARAL; CIOTTI; FONSECA, 2018).

The social-environmental context and the knowledge gap motivated the project "Biodiversity and functioning of a subtropical coastal ecosystem: subsidies to integrated management" (BIOTA-Araçá Project), involving over 170 researchers, from 2012 to 2017; CIOTTI; FONSECA, 2018). The BIOTA-Araçá Project was organized into twelve research groups, including the "Integrated Management" group that developed a PAR in the area, connecting researchers to local and regional management forums and society.

\section{Framework of the participatory action-research process and the strategy to promote social participation}

Participatory action-research (PAR) is based on an adaptive and heuristic perspective regarding the reality of local stakeholders, and on the development of participatory assessment and planning (CHAMBERS, 1994; CHEVALIER; BUCKLES, 2009). For the Araçá Bay context, we adapted two participatory instruments of Brazilian legislation (Agenda 21 and Orla Project) that foster social participation in decision-making ${ }^{2}$.

The PAR was carried out from 2014 to 2017 and involved the following steps: stakeholder mobilization and constant interaction with local community; the creation of a working-group in a local forum; the development of participatory workshops, so-called 
"BIOTA-Araçá Project Open Meetings", including phases of participative assessment and planning; the elaboration of a Local Plan for Sustainable Development of Araçá Bay (LPSD-Araçá); and the creation of a local management group (Araçá Guardians) for implementing the LPSD-Araçá and monitoring its actions. The degree of community engagement in the management process increased from Steps 1 to 3: (1) the research team played a significant role in mobilizing the local community for social participation; (2) strengthen perception of local community's own power and responsibilities into participative decision-making of coastal management, but still under researchers' active guidance; (3) local community emancipation to be protagonists in local management with minimum assistance from researchers (Figure 3). For a detailed description of activities refer to Santos et al. (2018a).

Figure 3. Framework of the participatory action-research (PAR) process and strategy to enhance social participation towards a more protagonist role of Araçá stakeholders in the management of Araçá Bay.

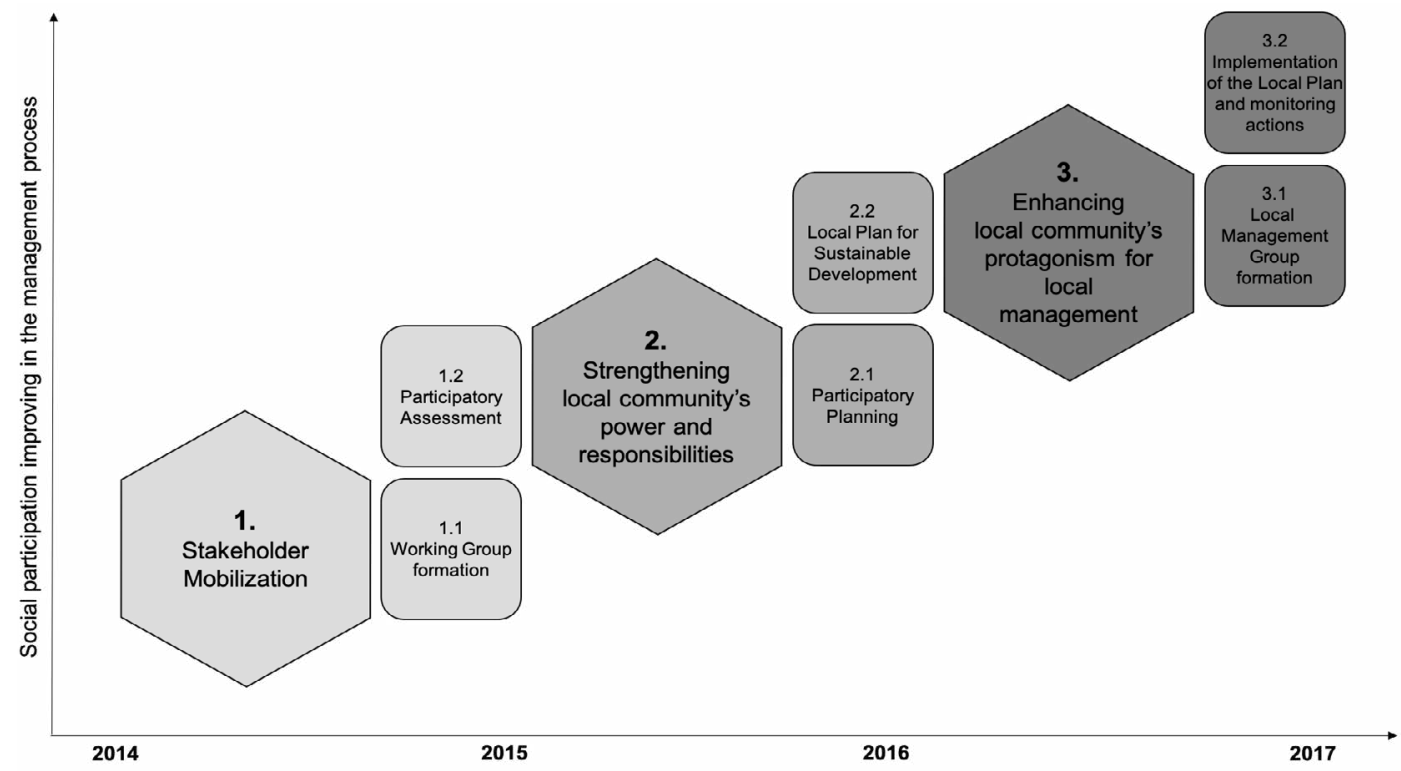

Source: authors (2021).

\subsection{Step 1: Stakeholder mobilization}

Besides PAR activities, the research team also interacted with local stakeholders in regional events, including beach clean-up campaigns, canoe regattas, meetings of regional forums, public hearings related to the port expansion project, a protest against the port expansion project organized by Araçá community leaders (SANTOS et al., 2018a), and in educational activities in a municipal public school (SANTOS et al., 2018b). The constant interaction with Araçá Bay's stakeholders was a mobilizing strategy to engage them in the 
participatory assessment and planning meetings, reinforced by the use of social media, email, phone calls, flyers, letters of invitation, personal and "door-to-door" invitations.

\subsubsection{Working Group formation}

In 2014, a partnership between the research team and the advisory committee of the Marine Protected Area of the Northern Coast of São Paulo State (APAMLN), established a working group within APAMLN's institutional structure. The "WorkingGroup Araçá" (WG Araçá) aimed to discuss the interests of society for the management of Araçá Bay (XAVIER; JACOBI; TURRA, 2018) and was composed of BIOTA-Araçá Project researchers, Araçá Bay dwellers, representatives of São Sebastião Port, technicians of environmental government institutions, environmental NGOs and educational institutions (XAVIER; JACOBI; TURRA, 2018). During the PAR, the group met ten times. meetings.

\subsubsection{Participatory Assessment}

The participatory assessment phase aimed to reinforce a common awareness about Araçá Bay (Figure 4a). In this phase, the research team mapped the main ecosystem services and threats of the bay by asking the participants:

$\square \quad$ What Araçá Bay provides for you today?

$\square$ What Araçá Bay can provide for you in the future?

What are the negative aspects of the bay today?

What can be the negative aspects of the bay in the future?

To create a welcoming and inviting environment to foster participation and engagement, the research team developed the following strategies (see Santos et al., 2018a for details):

$\square$ to call a poll to decide the best place, day of the week and time for the meetings;

$\square$ to have a team for moderation;

$\checkmark$ to include ice-breaking activities led by local community members in the beginning and in the end of meetings, such as yoga, music and group dynamics;

$\square$ to evaluate all the meetings, asking for positive and negative feedback and suggestions for improvement;

to implement the suggestions or justify when it was impossible to do so;

$\square$ to adopt a speech-object, which controlled and organized speech order;

$\checkmark$ to provide constant feedback by displaying the results of previous meetings in

3. This was an adaptation of the Strengths, Weakness, Opportunities and Threats framework (SWOT). For more information refer to SANTOS et al. 2018a. 
subsequent ones;

$\square$ to allow participants to validate and complement activities from previous meetings, regardless of their attendance.

3.2 Step 2: Strengthening local community's power and responsibilities

\subsubsection{Participatory Planning}

The participatory planning phase aimed to identify and discuss the main socialenvironmental problems of Araçá Bay (Figure 4b). The participants developed a common understanding of the problems' causes and consequences, proposed solutions, and mapped who should be involved in solving them (XAVIER; JACOBI; TURRA, 2019).

Figure 4. BIOTA-Araçá Project Open Meetings. a. Participatory assessment at Altivo's Beach in Araçá Bay. b. Participatory planning at the São Sebastião Environmental Observatory.

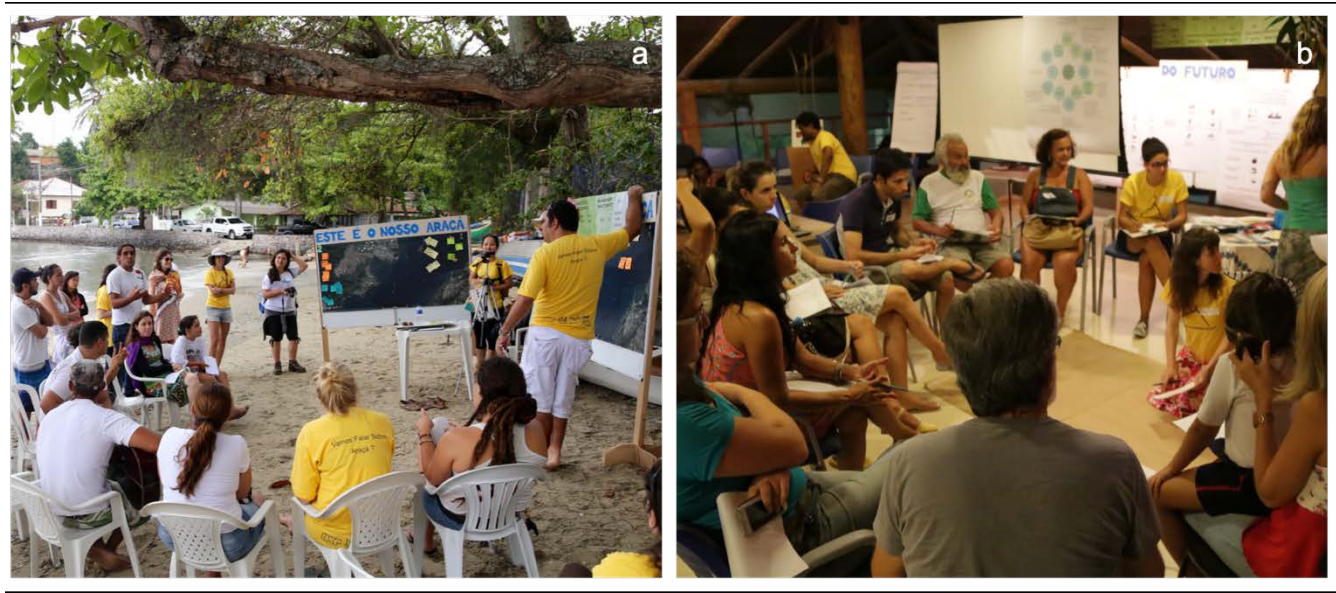

Photos: Authors (2015).

\subsubsection{Local Plan for Sustainable Development of Araçá Bay (LPSD-Araçá)}

Based on the perspective of knowledge integration and social learning, the research team coordinated the elaboration of the LPSD-Araçá (PLDS/Araçá, 2016). This document gathers the results from the participative assessment and planning phases and proposes general orientations and guidelines to solve the bay's problems, to ensure its sustainable use. Based on the perceptions of the local actors, such proposal emerged in a prospective scenario of port expansion and promoted an important dialogue on current and potential arrangements for the region.

3.3 Step 3: enhancing local community protagonists for local management 


\subsubsection{Local management group formation}

By the end of the process, participants created a group to continue the process and act in favor of the Araçá Bay, named the "Araçá Guardians". The group includes local community leaders, researchers, environmental NGOs, representatives of APAMLN and the São Sebastião municipal administration.

The group formation was one of the main outcomes of the participatory process and it was supported by the researchers after LPSD-Araçá launching. Since 2017, the Araçá Guardians led some LPSD-Araçá proposals implementation by meeting within the WG Araçá at the APAMLN and communicating with diverse regional stakeholders, such as City Hall departments and the São Paulo Water and Sewage Treatment Company. Until the publication of this paper, the Araçá Guardians group had 25 participants

\subsubsection{Implementation of the LPDS and monitoring actions}

The formation of the Araçá Guardians flagged a new stage of community engagement, demonstrating autonomous commitment to the management of the bay. In cooperation with the WG Araçá, the Araçá Guardians strengthened local social network, supported the implementation of the LPSD-Araçá guidelines, and enhanced the social control in Araçá Bay's management (XAVIER; JACOBI; TURRA, 2018; 2019). After the PAR, the participants were more confident and better qualified to engage in the bay's management debates. However, they complained about the end of the PAR and asked the research team to keep working with them to implement the LPDS-Araçá (SANTOS et al., in prep).

\section{Evidence of social participation improvement}

Over thirty years of the re-democratization process in Brazil, a diverse set of policies and tools has allowed social participation in environmental management in all administrative levels (SEIXAS et al., 2019). Besides formal arrangements, emotional drivers, such as threats and crises faced by social-ecological systems, can trigger social participation in environmental management (SEIXAS et al., 2019; GLASER et al., 2012).

The discussions about the Araçá Bay's future emerged with the licensing process for São Sebastião Port expansion. Although many Araçá's dwellers opposed the proposal, they were unable to present a cohesive contrary argument or an alternative proposal for the bay (NUNES, 2016). Thus, they relied on actions of a few Araçá dwellers or external organizations (e.g. NGOs, the Public Prosecutor's Office and researchers) to confront the situation. Such actions opposed the port expansion but they were not necessarily aligned with the local community's interests for the future of the bay, and they did not address solutions for the existing environmental problems.

The conflicting context and the need for greater local engagement favored the participatory process and social learning. Throughout the PAR, improvement in social participation was evidenced by: (1) building trust among participants; (2) increasing knowledge of social-ecological features of Araçá Bay; (3) acknowledging different per- 
spectives about the bay; and (4) improving the understanding of management dynamics and institutions.

\subsection{Building trust among participants}

The PAR connected dispersed community members to collaborate to the assessment and planning of their territory, gradually building trust among local community members and between them and other stakeholders.

For participatory processes, it is important that people feel that their opinions and knowledge will not be judged or rejected, and it can make a positive difference to the process (TORO; WERNECK, 2004). The welcoming and inclusive environment of the meetings encouraged participants to share their values and opinions, fostered consensual understanding and trust building, and improved the confidence of local community members to commit to their role in the process. The moderator was fundamental to maintain a fruitful dialogue among participants, securing the right to speech and the inclusion of divergent opinions on the debate.

Both the moderation and the dialogic environment were acknowledged by the participants on meetings' evaluation (SANTOS et al., 2018a). From the first to the last meeting, the interaction of local community members with other participants changed from a restrained behavior as they were very reserved and reluctant to give their opinion (step 1 of the framework), to a protagonist and collaborative behavior, evidenced by the emergence of the Araçá Guardians (step 3 of the framework).

The involvement of the research team with other local activities contributed to the process of building trust and fostered social participation in the activities of the PAR itself. Additionally, the active and continuous participation of local leaders in the PAR encouraged other actors and increased trust in the process and with the LPSD-Araçá under production (SANTOS et al., in prep).

\subsection{Increasing knowledge on social-ecological features of Araçá Bay}

The PAR applied an ecosystem-based approach (LONG et al., 2015) to the assessment and planning phases. This approach considered the relevant ecosystem features and services, the trade-offs between uses and users, the cumulative impacts from different human activities in the bay, and the need to maintain and recover the social-environmental quality of the bay.

The participatory assessment of the bay's ecosystem services fostered ecosystem thinking by bringing the concept of well-being and highlighting the integration between social and ecological processes. As an example, local dwellers reported better past fishing activity in Araçá Bay (food provision service) and a further decrease of it due to anthropic actions, such as sewage discharge, urban growth, and port activities (CARRILHO; SINISGALLI, 2018; STORI et al., 2019a). However, in a scenario of environmental recovery - as envisioned in the LPSD-Araçá - along with greater engagement of the local community, fishing activity may improve again, enhancing local food security, 
and maintaining traditional practices (CARRILHO; SINISGALLI, 2018).

The ecosystem-based approach enhanced the importance of integrated information to Araçá Bay management, including local traditional knowledge. Bridging different kinds of knowledge strengthen system resilience, stakeholders' cultural identity and sense of place, and commitment to local stewardship processes (STORI et al, 2017; OLIVEIRA; SANTOS; TURRA, 2018). The acknowledgment of traditional knowledge and its inclusion as one of the sources of information during the construction of the LPDS-Araçá, alongside scientific information, also enhanced the sense of ownership and enabled a process of knowledge integration and valorization (STORI et al., 2019a, XAVIER; JACOBI; TURRA, 2018). This was crucial to the participants to see themselves as a part of the LPDS-Araçá and to feel accountable for its implementation.

\subsection{Acknowledging different perspectives about the bay}

The PAR meetings accounted for 141 participants (PLDS/ARAÇÁ, 2016). Civil society was represented by Araçá's dwellers and its neighborhoods, fishermen and dwellers of other districts (49\%), and local and regional non-governmental organizations (9\%). Science and research interests were represented by universities and research institutions (28\%). The government sector (11\%) was represented by the technicians of APAMLN, employees of the Municipal Secretariat of Environment, teachers from the Municipal Secretariat of Education, advisers of an alderman of São Sebastião City Council and attorneys from the Public Prosecutor's Office. The private sector (3\%) was represented by an employee of São Sebastião Port, local merchants and businessmen in general.

All those people have their own beliefs and values systems, so the research team focused on establishing common goals, discussing solutions, mediating internal conflicts, and finding new approaches for different stakeholders to work together. Bridging stakeholders may lead to "a sense of ownership over the process and outcomes" (REED, 2008, p. 2420), balance power dynamics (REED et al., 2018) and increase the social capital of the community (NUNES, 2016).

One of the employed approaches was information translation: communication of the statements from different worldviews in a language accessible to all participants (CALLON 1986; SPRUIJT et al., 2014). The translation is pivotal to establish a collective frame of the problems and construct common objectives (CALLON, 1986; SPRUIJT et al., 2014; XAVIER, JACOBI, TURRA, 2018). In the Araçá Bay PAR, the researchers acted as moderators who engaged Araçá stakeholders in sharing their knowledge, codified the information and set a common language. In our case, the translation of the importance of ecosystem services and the causes of current and future problems allowed participants to identify the external threats and the internal weaknesses, and develop possible solutions for the social-ecological system problems.

The participatory assessment phase evidenced that the challenges for the sustainable management of Araçá Bay were more numerous than only the port expansion project. In the planning meetings, other problems that directly affected Araçá dwellers were mapped and prioritized (Figure 5). Initially disregarded as a priority, the problem of "Low social 
involvement" emerged as a fundamental one through the planning phase and was the first tackled by the group, which was in itself a way to improve social involvement of local citizens in management processes.

Figure 5: Social-environmental problems of Araçá Bay, from the most (1) to the least (12) listed in the Local Plan for Sustainable Development of Araçá Bay.

1.

12. Lack of infrastructure for
tourism and leisure activities

11.

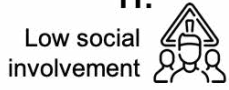

10.
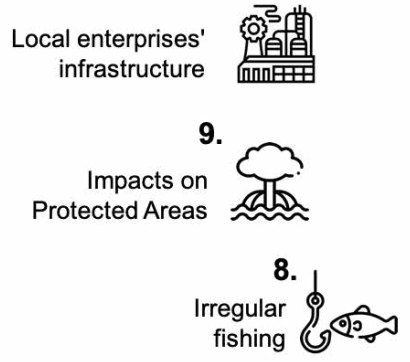

Araçá Bay's problems
Sewage discharge and contamination
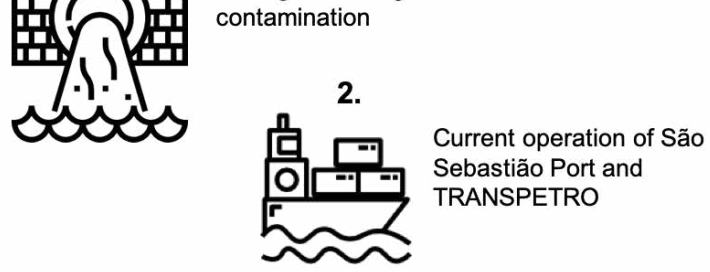

3.

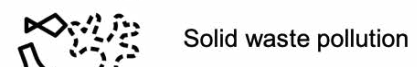

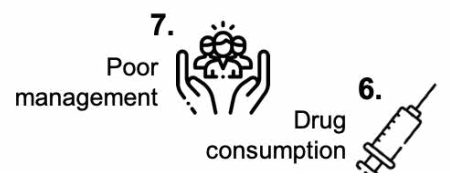

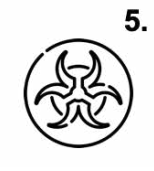

5.

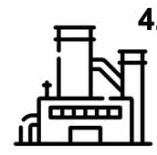

4. Industrial \& Urban growth

Chemical pollution

Source: authors based on PLDS/Araçá (2016).

4.4 Improving the understanding of management dynamics and institutions

PAR can foster participants to develop knowledge and skills about civic processes that govern their lives and territories (BALLARD; BELSKY, 2010). In our case study, step 3 of the framework was fostered by the interactions of Araçá dwellers with local and regional forums and management institutions, especially with the WG Araçá. The intersection of actors in the WG Araçá and Araçá Guardians motivated a synergy of actions and meetings that optimized the groups' planning and articulation with institutions, such as the Water and Sewage Treatment Company of São Paulo State, City Hall and the Public Prosecutor's Office. Although the Araçá Guardians are not a formal institution, they are acknowledged as Araçá local leadership by other actors and institutions.

From this perspective, one can state that the Araçá Bay community climbed some rungs on the social participation ladder, described by Arnstein (1969). They came from the bottom rungs of non-participation to varying degrees of tokenism, i.e. local actors 
from Araçá Bay are more mobilized, they have a voice as a community, but they still lack the power to ensure that their goals will be heeded by the decision-makers. We understand that this is a long-term process and that there is a long way ahead to higher rungs, but we can say that during the three years of PAR, there was unequivocal evidence of improvement in social engagement in the Araçá Bay region.

\section{Challenges to local management}

Despite the progress in social participation, many obstacles remain to be overcome: tackling internal conflict in the management groups; overcoming bureaucracies in government structure; building alternative strategies to solve complex issues; and keeping the actors mobilized and engaged in the management process.

The brief trajectory of Araçá Guardians allows some considerations on the conduct and actions of the group. Internal conflicts challenge the effectiveness of collective actions, especially regarding the context of a recent democracy in which people's behavior is based on favor exchanges and patronage (SEIXAS et al., 2019). The local participatory culture or the previous level of social engagement affect long term engagement (REED et al., 2018). It is important to highlight that in Araçá Bay,, the local inhabitants had a very individualistic behavior before the PAR. During the PAR, many internal conflicts within the local community were put aside by the need for alliances in the face of a common threat (the port expansion) and the moderation of researchers. However, when the research project ended and the harbor license was revoked, individual issues, such as political disagreements and power disputes, began to overlap collective interests and actions and hindered the implementation of the LPSD-Araçá proposals.

The high degree of multiplicity and fragmentation of government sectors, as well as political power disputes and conflicting management agendas, also hamper the participatory process (SEIXAS et al., 2019). In the Araçá Bay, consecutive changes in APAMLN managers (four different managers from 2015 to 2018) (STORI et al., 2019b) hindered the implementation of LPSD-Araçá proposals. Commonly, the government support on participatory management is more dependent on staff members' beliefs about the process than the organization's agenda itself. Therefore, changes in the staff may hinder an ongoing participatory process (SEIXAS et al., 2019).

The urban social problems identified in LPSD-Araçá are overly complex and involve multiple stakeholders and policy arenas. The Araçá Guardians tried to solve local issues related to sewage discharge and solid waste in the Araçá Bay and, after experiencing success and defeats, the group recognized the need for reorganization and planning for better strategies and actions. Actions are still being questioned and re-discussed for the implementation of the LPSD-Araçá due to increased recognition of the problems' complexity and the need to build institutional arrangements to support the LPSD-Araçá (XAVIER; JACOBI; TURRA, 2019).

Due to the complexity of the elected problems and the incipient success in implementing LPDS-Araçá actions so far, the Araçá Guardians have undergone a challenging 
period of social learning single loop involving the development of alternative strategies to solve problems and improve results. Taking too long or not achieving the common goals may lead to a feeling of frustration (TRIMBLE; ARAÚJO; SEIXAS, 2014). Therefore, the absence of concrete results in the short term can be a demobilization factor for the Araçá Guardians. The difficulty in overcoming internal conflicts seems to be leading stakeholders back to their previous individualist behavior. Direct partnerships with decision-makers may offer the opportunity for those that wish to follow their agendas without the need for long term participatory processes and negotiating with several stakeholders or institutions that may not influence the government decision-making (EMPINOTTI, 2011). Consequently, keeping Araçá Guardians mobilized and engaged requires a deep understanding of the local conflicts, promoting communication strategies and investing in policy literacy activities.

\section{Final remarks}

The PAR aimed to move Araçá Bay's stakeholders from a low degree of social capital, mobilization, and trust among themselves towards a better informed and engaged community, committed to the sustainability of Araçá Bay's ecosystem services and uses. The most prominent changes in social participation are the creation of the Araçá Guardians and WG Araçá as forums for cooperation among stakeholders, the participation of Araçá dwellers in other regional forums, and the elaboration of a plan to solve the main problems identified by local stakeholders.

Through the PAR, the early and active engagement of the community resulted in greater autonomy and sense of ownership of the process, equalizing power relationships and enhancing social participation. Considering the context of Araçá Bay, the research team acknowledges that more actions could have been implemented that would gradually diminish the dependence of the community from the facilitation team, such as building an agenda for implementing actions collectively, continuing to support local cultural events, and nourishing links between the Araçá community and other stakeholders. The fact that the PAR was an initiative proposed by the researchers can be a factor that led the community to rely on the researchers to act. A genuine participatory process arising from the community would provide more elements to keep this network connected and vigilant. However, in a system where the community is demobilized, the researchers' performance as facilitators in the elaboration of a sustainable development plan proved to be crucial to lead this community out of an inertia state and achieve a higher stage on the participation ladder.

Despite identified advancements, the sustainable future for Araçá Bay is not guaranteed and may never be. The port expansion and other economic development projects will be constantly threatening this social-ecological system. Thus, the stakeholders' network supporting Araçá Bay conservation must be kept connected and vigilant. Future research is required to monitor the actions of WG Araçá, Araçá Guardians and the social participation of Araçá stakeholders in other management forums, as well to devise mechanisms to boost and maintain the engagement needed for long-term partici- 
patory processes.

\section{Acknowledgments}

The authors thank the São Paulo Research Foundation (FAPESP) for the financial support [grant number 2011/50317-5, CRS number 2013/02441-4, FTS number: 2014/16004-8, and LYX number: 2017/21797-5], the Coordenação de Aperfeiçoamento de Pessoal de Nivel Superior [Institutional Grants from IOUSP], the Oceanographic Institute of the University of São Paulo for the institutional support, the participants in the LPSD/Araçá process, and the reviewers for the insightful comments.

\section{References}

ALMEIDA, D.C.R.; CUNHA, E.S.M. A Análise da decisão democrática: princípios, conceitos e variáveis relevantes. In: PIRES, R.R. Efetividade das instituições participativas no Brasil: estratégias de avaliação. Brasília: Ipea, 2011. v. 7, p. 109-124.

AMARAL, A.C.Z. et al. Araçá: biodiversidade, impactos e ameaças. Biota Neotropica, v. 10, n. 1, p. 219-264, 2010.

AMARAL, A.C.Z. et al. (Org.). Life in Araçá Bay. São Paulo: Lume, 2016.

AMARAL, A.C.Z.; CIOTTI, A. M; FONSECA, G. Biodiversity and functioning of a subtropical coastal ecosystem: Subsidies for integrated management. Ocean\&Coastal Management, v. 164, p. 1-3, 2018.

ARNOLD, J.S.; FERNANDEZ-GIMENEZ, M. Building Social Capital Through Participatory Research: An Analysis of Collaboration on Tohono O'odham Tribal Rangelands in Arizona. Society and Natural Resources, v. 20, p. 481-495, 2007.

ARNSTEIN, S.R. A ladder of participation. Journal of the American Institute of Planners, v. 35, n. 4, p. 216-224, 1969.

BALLARD, H.L.; BELSKY, J.M. Participatory action research and environmental learning: implications for resilient forests and communities. Environmental Education Research, v. 16, p. 611-627, 2010.

BERKES, F. Evolution of co-management: role of knowledge generation, bridging organizations and social learning. Journal of Environmental Management, v. 90, p. 1692-1702, 2009.

BERKES, F; FOLKE, C. (Eds.). Linking sociological and ecological systems: management practices and social mechanisms for building resilience. New York: Cambridge University Press, 1998.

BROWN, K.; TOMPKINS, E.L.; ADGER, W.N. Making waves: integrating coastal conservation and development. New York: Earthscan, 2002.

CALLON, M. Eléments pour une sociologie de la traduction: la domestication des coquilles 
Saint- Jacques et des marins-pêcheurs dans la baie de Saint-Brieuc. L'Année Sociologique, v. 36, p. 169-208, 1986.

CARRILHO, C.D. SINISGALLI, P.A.A. Contributions to Araçá Bay management: The identification and valuation of ecosystem services. Ocean \& Coastal Management, v. 164, p. 128-135, 2018.

CHAMBERS, R. The origins and practices of participatory rural appraisal. World development, v. 22, n. 7, p. 953-969, 1994.

CHEVALIER, M.C.; BUCKLES, D.J. Guía para La Investigación Colaborativa y La Movilización Social. Centro Internacional de Investigaciones para El Desarrollo. Ottawa: Plaza y Valdez, 2009.

DERAK, M. et al. A proposed framework for participatory forest restoration in semiarid areas of North Africa. Restoration ecology. v. 26, p. S18-S25, 2018.

DE VENTE, J. et al. How does the context and design of participatory decision-making processes affect their outcomes? Evidence from sustainable land management in global drylands. Ecology and Society, v. 21, n. 2, 2016.

EMPINOTTI, V.L.E se eu não quiser participar? O caso da não participação nas eleições do comitê de bacia do rio São Francisco. Ambiente \& Sociedade, v. 14, n. 1, p. 195-210, 2011.

FARIA, C.F.; RIBEIRO, U.C.; Desenho Institucional: Variáveis relevantes e seus efeitos sobre o processo participativo. In: PIRES, R.R. Efetividade das instituições participativas no Brasil: estratégias de avaliação. Brasília: Ipea, 2011, v. 7, p.124-135.

GARMENDIA, E.; STAGL, S. Public participation for sustainability and social learning: Concepts and lessons from three case studies in Europe. Ecological Economics, v. 69, n. 8, p. 1712$1722,2010$.

GLASER, M., et al. Towards global sustainability analysis in the Anthropocene, In: GLASER, M. et. al. Human-Nature Interaction in the Anthropocene: Potentials of Social-Ecological Systems Analysis, New York: Routledge, 1 Ed., 2012, p. 193-222.

LONG, R.D.; CHARLES, A.; STEPHENSON, R.L. Key principles of marine ecosystem-based management. Marine Policy, v. 57, p. 53-60, 2015.

MCTAGGART, R. (Ed.). Participatory action research: international contexts and consequences. New York: Suny Press, 1997.

MOBERG, F., SIMONSEN S.H. What is resilience? An introduction to social-ecological research. Stockholm Resilience Centre: Stockholm, Sweden, 20p. 2014.

MURO, M.; JEFFREY, P. A critical review of the theory and application of social learning in participatory natural resource management processes. Journal of Environmental Planning and Management, v. 51, n. 3, p. 325-344, 2008.

NETO, A.L. et al. Ação Civil Pública para a proteção do meio ambiente: Aspectos jurídicos da 
proposta de ampliação do Porto de São Sebastião. In: SANTOS, C.R.; TURRA, A. Rumos da sustentabilidade costeira: uma visão do Litoral Norte Paulista. São Paulo: Instituto Oceanográfico da Universidade de São Paulo. 2017, p. 415-450.

NUNES, F.O. Análise de redes sociais como subsídio para a gestão ambiental: um estudo de caso. São Paulo: USP, 71p. Dissertação - Programa de Pós-Graduação em Modelagem de Sistemas Complexos, Escola de Artes, Ciências e Humanidades, Universidade de São Paulo. São Paulo, 2016.

OLIVEIRA, N.R.; SANTOS, C.R.; TURRA, A. Percepção ambiental como subsídio para gestão costeira da Baía do Araçá, Litoral Norte do Estado de São Paulo, Brasil. Desenvolvimento e Meio Ambiente, v. 44, Edição especial: X Encontro Nacional de Gerenciamento Costeiro, p. 140-163, 2018.

PERES, C.M. et al. Stakeholders perceptions of local environmental changes as a tool for impact assessment in coastal zones. Ocean \& Coastal Management, v. 119, p. 135-145, 2016.

PETERSON, N.D. Excluding to include: (Non) participation in Mexican natural resource management. Agriculture and Human Values, v. 28, p. 99-107, 2011.

PLDS/ARAÇÁ. Plano Local de Desenvolvimento Sustentável da Baía do Araçá. Org: TURRA, A. et al. 1ª Edição. São Paulo: Instituto Oceanográfico da Universidade de São Paulo, 2016.

REED, M.S. et al. A theory of participation: what makes stakeholder and public engagement in environmental management work? Restoration Ecology, v. 26, p. 7-17, 2018.

REED, M.S. Stakeholder participation for environmental management: A literature review. Biological Conservation, v. 141, n. 10, p. 2417-243, 2008.

REED, M.S. et al. What is Social Learning? Ecology and Society, v.15, n.4, (online), 2010.

SANTOS, C.M. Diagnóstico de rede sócio técnica do Araçá, município de São Sebastião, São Paulo: atores, usos, relações sociais e suas implicações para gestão ambiental. São Paulo: USP, 2012, 43p. Monografia, Escola de Artes, Ciências e Humanidades. Universidade de São Paulo. São Paulo, 2012.

SANTOS, C.R.; TURRA, A. Rumos da sustentabilidade costeira: uma visão do Litoral Norte Paulista. São Paulo: Instituto Oceanográfico da Universidade de São Paulo. 2017.

SANTOS, C.R.; BORGES, P.F.D.; TURRA, A. Inquéritos civis e a atuação multi-institucional em defesa da Baía do Araçá. In: SANTOS, C.R.; TURRA, A. Rumos da sustentabilidade costeira: uma visão do Litoral Norte Paulista. São Paulo: Instituto Oceanográfico da Universidade de São Paulo. 2017, p.333-385.

SANTOS, C.R. et al. Prática da Gestão Costeira Integrada: da mobilização à elaboração de um Plano Local de Desenvolvimento Sustentável. In: AMARAL, A.C.Z.et al. Métodos de estudo em ecossistemas costeiros: biodiversidade e funcionamento. $1^{\mathrm{a}} \mathrm{Ed}$. Campinas: Biblioteca/UNICAMP, 2018 a., p .273-305.

SANTOS, C.R. et al. A collaborative work process for the development of coastal environmental 
education activities in a public school in São Sebastião (São Paulo State, Brazil). Ocean\&Coastal Management, v. 164, p. 147-155, 2018 b.

SANTOS, C.R. et al. Fatores que contribuem no envolvimento de atores em processos de planejamento participativo. In prep.

SEIXAS, C.S. Abordagens e técnicas de pesquisa participativa em gestão de recursos naturais. In: VIEIRA, P.V.; BERKES, F; SEIXAS, C.S. Gestão Integrada e Participativa de Recursos Naturais: conceitos, métodos e experiências. Florianópolis: Secco/APED, 2005, p.73-105.

SEIXAS, C.S. et al. Collaborative Coastal Management in Brazil: Advancements, Challenges, and Opportunities. In: SALAS S., BARRAGÁN-PALADINES M., CHUENPAGDEE R. Viability and Sustainability of Small-Scale Fisheries in Latin America and The Caribbean. MARE Publication Series, 2019, v .19. p .425-451.

SPRUIJT, P. et al. Roles of scientists as policy advisers on complex issues: A literature review. Environmental Science and Policy, v. 40, p.16-25, 2014.

STORI, F.T. et al. Gestão Costeira Integrada com vistas à resiliência de sistemas socioecológicos para sustentabilidade dos bens e serviços ecossistêmicos: reflexões de um coletivo. In: MOURA, G.G.M. Avanços em Oceanografia Humana: o Socioambientalismo nas Ciências do Mar. Jundiaí: Paco, 2017. p.233-284.

STORI, F.T. et al. Traditional Ecological Knowledge Supports Ecosystem-Based Management in Disturbed Coastal Marine Social-Ecological Systems. Frontiers in Marine Science. v .6, p .571, 2019 a.

STORI, F. T., SHINODA, D. C., TURRA, A. Sewing a blue patchwork: an analysis of marine policies implementation in the southeast of brazil. Ocean $\&$ Coastal Management. v. 168, p $.322-339.2019$ b.

TORO, J.B.; WERNECK, N.M.D. Mobilização social: um modo de construir a democracia e a participação. Belo Horizonte: Autêntica, 2004.

TRIMBLE, M.; ARAUJO, L.G.; SEIXAS, C.S. One party does not tango! Fishers' non-participation as a barrier to co-management in Paraty, Brazil. Ocean $\&$ Coastal Management, v. 92, p. 9-18, 2014.

TURRA, A. et al. Environmental impact assessment under an ecosystem approach: the São Sebastião harbor expansion project. Ambiente \& Sociedade, v. 20, n .3, p. 155-176, 2017.

XAVIER, L.Y.; JACOBI, P; TURRA, A. On the advantages of working together: Social Learning and knowledge integration in the management of marine areas. Marine Policy, v .88, p .139-150, 2018.

XAVIER, L.Y.; JACOBI, P.; TURRA, A. Local Agenda 21: Planning for the future, changing today. Environmental Science and Policy, v. 101, p. 7-15, 2019. 
Natalia de Miranda Grilli

$\square$ nmgrilli@gmail.com

ORCiD: https://orcid.org/0000-0002-6634-3992

\section{Mariana Martins de Andrade}

$\square$ mariana.martinsdeandrade@gmail.com

ORCiD: https://orcid.org/0000-0001-5161-6372

\section{Luciana Yokoyama Xavier}

$\square$ lyxavier@usp.br

ORCiD: https://orcid.org/0000-0001-7074-9365

\section{Cláudia Regina Santos}

$\square$ biolsantos@hotmail.com

ORCiD: https://orcid.org/0000-0002-2852-1268

\section{Fernanda Terra Stori}

$\square$ f.terra.stori@gmail.com

ORCiD: https://orcid.org/0000-0002-2827-5706

\section{Cauê Dias Carrilho}

$\square$ cauecarrilho@usp.br

ORCiD: https://orcid.org/0000-0001-8338-5193

\section{Felipe Otavio Nunes}

$\square$ felipeotavio.nunes@gmail.com

\section{Caiuá Mani Peres}

$\square$ caiua.peres@usp.br

ORCiD: https://orcid.org/0000-0001-7169-9064
Submitted on: 30/01/2020

Accepted on: 12/12/2020

2021;24e:02551 


\title{
Melissa Vivacqua
}

๑mv.rodrigues@unifesp.br

ORCiD: https://orcid.org/0000-0001-5151-0500

\section{Thiago Zagonel Serafini}

$\square$ thiagoserafini@ufpr.br

ORCiD: https://orcid.org/0000-0002-4038-8009

\section{Paulo Antonio de Almeida Sinisgalli}

$\square$ psinisgalli@usp.br

ORCiD: https://orcid.org/0000-0001-7822-3499

\section{Cristiana Simão Seixas}

๑csseixas@unicamp.br

ORCiD: https://orcid.org/0000-0002-4464-2094

\section{Pedro Roberto Jacobi}

ఐprjacobi@gmail.com

ORCiD: https://orcid.org/0000-0001-6143-3019

\author{
Alexander Turra \\ $\square$ turra@usp.br \\ ORCiD: https://orcid.org/0000-0003-2225-8371
}

How to cite: GRILLI, N.M.; ANDRADE, M.M.; XAVIER, L.Y.; SANTOS, C.R.; STORI, F.T.; CARRILHO, C.D.; NUNES, F.O.; PERES, C.M.; VIVACQUA, M.; SERAFINI, T.Z.; SINISGALLI, P.A.A.; SEIXAS, C.S.; JACOBI, P.R.; TURRA, A. Step by step: a participatory action-research framework to improve social participation in coastal systems. Ambiente \& Sociedade. São Paulo, v. 24, p. 1-22, 2021. 


\section{Passo-a-passo: uma estrutura de pesquisa- ação participativa para aumentar a participação social em sistemas costeiros}

\author{
Natalia de Miranda Grilli \\ Mariana Martins de Andrade \\ Luciana Yokoyama Xavier \\ Cláudia Regina Santos \\ Fernanda Terra Stori \\ Cauê Dias Carrilho \\ Felipe Otavio Nunes
}

\author{
Caiuá Mani Peres \\ Melissa Vivacqua \\ Thiago Zagonel Serafini \\ Paulo Antonio de Almeida Sinisgalli \\ Cristiana Simão Seixas \\ Pedro Roberto Jacobi \\ Alexander Turra
}

São Paulo. Vol. 24, 2021

Artigo Original
Resumo: Participação social qualifica a tomada de decisão, e, embora seja considerada um direito civil em diversas democracias, ainda é um desafio. $\mathrm{O}$ artigo apresenta evidências e discute mudanças na participação social de uma comunidade costeira no sudeste do Brasil (Baía do Araçá), resultante de uma pesquisa-ação participativa. Durante três anos, desenvolveu-se um processo de mobilização social, diagnóstico e planejamento participativos, que produziu um plano de ações. Evidências do aumento da participação social dos stakeholders foram: (1) construção de confiança entre os participantes; (2) aumento do conhecimento de características socioecológicas da Baía do Araçá; (3) reconhecimento das diferentes perspectivas sobre a baía; (4) entendimento sobre processos e instituições de gestão. Esse processo levou à criação de um grupo de gestão local, que tem o potencial de implementar o plano de desenvolvimento sustentável.

Palavras-chave: Aprendizagem social; Sistemas socioecológicos; Baía do Araçá.

Como citar: GRILLI, N.M.; ANDRADE, M.M.; XAVIER, L.Y.; SANTOS, C.R.; STORI, F.T.; CARRILHO, C.D.; NUNES, F.O.; PERES, C.M.; VIVACQUA, M.; SERAFINI, T.Z.; SINISGALLI, P.A.A.; SEIXAS, C.S.; JACOBI, P.R.; TURRA, A. Passo-a-passo: uma estrutura de pesquisa-ação para aumentar a participação social em sistemas costeiros. Ambiente \& Sociedade. São Paulo, v. 24, p. 1-22, 2021. 


\section{Paso a paso: un marco de investigación- acción participativa para aumentar la participación social en los sistemas costeros}

\author{
Natalia de Miranda Grilli \\ Mariana Martins de Andrade \\ Luciana Yokoyama Xavier \\ Cláudia Regina Santos \\ Fernanda Terra Stori \\ Cauê Dias Carrilho \\ Felipe Otavio Nunes
}

\author{
Caiuá Mani Peres \\ Melissa Vivacqua \\ Thiago Zagonel Serafini \\ Paulo Antonio de Almeida Sinisgalli \\ Cristiana Simão Seixas \\ Pedro Roberto Jacobi \\ Alexander Turra
}

São Paulo. Vol. 24, 2021

Artículo original
Resumen: Participación social califica la toma de decisiones, y aunque se considera un derecho civil en muchas democracias, sigue siendo un desafío. El artículo presenta evidencias y discute cambios en la participación social de una comunidad costera en Brasil (Bahía de Araçá), como resultado de una investigación de acción-participativa. Durante tres años, se desarrolló un proceso de movilización social, diagnóstico y planificación participativa, que produjo un plan de acción. La evidencia de una mayor participación social de los interesados fue: (1) generar confianza entre participantes; (2) mayor conocimiento de las características socioecológicas de la bahía; (3) reconocimiento de las diferentes perspectivas en la bahía; (4) comprensión de los procesos e instituciones de gestión. Este proceso ha llevado a la creación de un grupo local de gestión, que tiene el potencial de implementar el plan de desarrollo sostenible.

Palabras-clave: Aprendizaje social; Sistemas socioecológicos; Bahía Araçá.

Como citar: GRILLI, N.M.; ANDRADE, M.M.; XAVIER, L.Y.; SANTOS, C.R.; STORI, F.T.; CARRILHO, C.D.; NUNES, F.O.; PERES, C.M.; VIVACQUA, M.; SERAFINI, T.Z.; SINISGALLI, P.A.A.; SEIXAS, C.S.; JACOBI, P.R.; TURRA, A. Paso a paso: marco de investigación de acción-participativa para mejorar participación social em sistemas costeros. Ambiente \& Sociedade. São Paulo, v. 24, p. 1-22, 2021. 